Session 2002-2103

\title{
Fast Track to Achievement II: Increasing Academic Performance and Retention of Engineering Freshmen by Promoting Achievement Behaviors
}

\author{
Grace E. Mack, John A. Wheatland, and Kisha Johnson \\ Morgan State University
}

\begin{abstract}
In making the transition from high school to college, engineering freshmen can benefit from guidance by upperclassmen on how to meet the challenges of engineering and how to negotiate the college environment. Upperclassmen, particularly those with a proven track record of academic achievement and leadership, are credible sources and powerful role models for engineering freshmen. This assumption formed the basis for development of a freshman retention program, "Fast Track to Achievement." The primary strategy of Fast Track is to engage teams of upperclassmen in dialogue with groups of freshmen in a series of workshops focusing on three themes -"Mastering Mathematics," "Making It in Engineering," and "Planning to Graduate." The goal of the program is to expose the greatest number of freshmen to successful engineering undergraduates who can speak from experience on how to adjust to the rigors of the engineering curriculum, earn the best grades, and make the freshman year a good foundation for achievement in engineering. This paper describes the training, implementation, and evaluation of the Fast Track to Achievement Programs and its effect on freshman academic performance and retention.
\end{abstract}

Introduction

Nearly twenty-five years ago, Tinto ${ }^{8}$ proposed a conceptual model of college student attrition. Essentially, Tinto theorized that dropout behavior is a longitudinal process based on the quality of the interaction between the student and the institution's academic and social systems. When precollege background characteristics and experiences are held constant, persistence in college is a result of the student's level of academic and social integration in the institution. Academic integration is related to the student's goal commitment (to graduate) and the quality of social integration is related to the student's commitment to the institution. The greater the academic and social integration, the greater the student's institutional and goal commitment and the greater the probability the student will persist. Studies conducted by Pascarella and Chapman ${ }^{3}$, Pascarella and Terenzini ${ }^{5}$, and Terenzini and Pascarella ${ }^{7}$ to test the validity of Tinto's model generally support the relationship between social integration and persistence, particularly at four-year residential institutions and for women. These and other studies have concluded that Tinto's model has "reasonable predictive power in explaining variance in freshman year persistence/voluntary withdrawal"4

Social integration is the result of "informal peer group associations, semi-formal extra-curricular activities and interaction with faculty and administrative personnel of the college" 8 . Tinto 
theorized that of all the possible types of social interaction, peer-group associations are the most salient in social integration and most directly impact the student's institutional commitment. The Fast Track to Achievement program is an effort to provide freshmen with a quality, first-time peer group experience as a means of motivating freshmen to stay linked to the engineering community. The program is similar to an activity in the Engineering 101 course at Clemson University where, each semester, a panel of sophomores, juniors, and seniors dialogue with freshmen and have a frank discussion of their experiences in engineering. ${ }^{2}$ Like the Fast Track team leaders, the panelists represent a variety of engineering fields and a wide range of grade point averages. Both of these programs suggest a process for peer-group interaction, the key element in social integration.

\section{Program Goals}

The goals of the Fast Track to Achievement program are to:

- ease the transition from high school to college for engineering freshmen,

- focus as many freshmen as possible on expectations for engineering students and on behaviors that promote success and achievement in engineering, and

- introduce freshmen to successful upper-class role models that can provide guidance and make a personal statement that engineering is both achievable and attainable if they are willing to adopt behaviors that lead to success in engineering.

\section{Program Design}

The major components of the program are three 25 minute workshops, namely, "Mastering Mathematics," "Making It In Engineering," and "Planning To Graduate." Twenty-five upperclassmen are organized into teams of three to four. Each team serves as workshop facilitators for groups of 25-30 freshmen. Upperclassmen who are engineering organization leaders, academic achievers, and who have a general interest in working with new freshmen, volunteer their services to organize and implement the program. The program has been conducted for first-time freshmen five times -- Fall 1997 (F97), Fall 1998 (F98), Fall 1999 (F99), Fall 2000 (F00), Fall 2001 (F01).

Two models were developed to involve students in the program. In F97, the first year of the program, the Open Invitation Model invited freshmen and transfer students (via posters and announcements) to come to the student center on main campus to participate in a half-day Saturday program. Approximately $50 \%$ of eligible students attended the voluntary program. In F98, F99, F00, F01, the Open Invitation Model was abandoned for the Integration Model, a more inclusive model designed to increase the level of freshman participation. This model integrates the Fast Track program in the "Introduction to Engineering" course (ORIE 104), the orientation course for engineering freshmen. In the Integration Model, freshmen are required to participate in the program.

The program is offered in two overlapping sessions of about 100 students each (Table 1). Students who attend session one are enrolled in section one of Introduction to Orientation (ORIE 104:001) and those that are assigned to attend session two are enrolled in section two of Introduction to Orientation (ORIE 104:002). The program includes an opening general session

Proceedings of the 2002 American Society for Engineering Education Annual Conference \& Exposition Copyright @ 2002, American Society for Engineering Education” 
that explains the purpose and procedure for the program, three workshops (Table 2), and a closing session with a motivational speaker(s). Participants are divided into three groups by assignment of a code. Each group of freshmen rotates through each of the three workshops. Packets are distributed in the general session. The packet includes a program agenda, the tutoring schedule for the semester, and the Fast Track Engineering Freshman Handbook. The handbook is a compilation of workshop notes, campus and engineering school information, departmental audit forms, tidbits about life as an engineering student -- the "how to" "where to", and "who to" that every engineering freshman should know. Participants are given and encouraged to read two NACME (National Action Council of Minorities in Engineering) publications, "Academic Gamesmanship: Becoming a Master Engineering Student" and "Design for Excellence: How to Study Smartly." Participants also receive incentives for participation (i.e., hat, pennant, planners, coffee mug) with engineering/university logo. Scheduling, space, resource materials, selection of workshop facilitators is coordinated by the Recruitment/Retention Coordinator and the Director of Freshmen Programs. Ideally, the program is implemented within the first month of the first semester of the freshman year. The program is supported by funds earmarked for retention and, for the past two years, by a grant from the Lockheed Martin Corporation. The Lockheed Martin grant supported the development of the freshman handbook and the training manual for facilitators, which was piloted in Fall 2001 and Spring 2002.

TABLE 1

Fast Track to Achievement Program Schedule

\begin{tabular}{|c|c|c|c|}
\hline & $\begin{array}{c}\text { Introduction to Orientation } \\
\text { ORIE 104:001 }\end{array}$ & & $\begin{array}{l}\text { Introduction to Orientation } \\
\text { ORIE 104:002 }\end{array}$ \\
\hline 10:00 - 10:10 & $\begin{array}{l}\text { Opening Session } \\
\text { Schaefer Lecture Hall }\end{array}$ & & \\
\hline $10: 15-10: 40$ & $\begin{array}{l}\text { Planning to Graduate - S2O2 } \\
\text { Mastering Mathematics - S2O3 } \\
\text { Making It In Engineering - } S 204\end{array}$ & & \\
\hline $10: 45-11: 10$ & $\begin{array}{l}\text { Planning to Graduate } \\
\text { Mastering Mathematics } \\
\text { Making It In Engineering }\end{array}$ & $11: 00-11: 10$ & $\begin{array}{l}\text { Opening Session } \\
\text { Schaefer Lecture Hall }\end{array}$ \\
\hline 11:15- 11:40 & $\begin{array}{l}\text { Planning to Graduate } \\
\text { Mastering Mathematics } \\
\text { Making It In Engineering }\end{array}$ & $11: 15-11: 40$ & $\begin{array}{l}\text { Planning To Graduate - S208-209 } \\
\text { Mastering Mathematics -ITV } 126 \\
\text { Making It In Engineering -ITV } 122\end{array}$ \\
\hline \multirow[t]{3}{*}{ 11:45 - 12:00 } & $\begin{array}{ll}\text { Closing Session } \\
\text { Schaefer Lecture Hall } \\
\circ \quad \text { Guest Speaker(s) } \\
\circ \quad \text { Wrap-Up/Evaluation }\end{array}$ & $11: 45-12: 10$ & $\begin{array}{l}\text { Planning To Graduate } \\
\text { Mastering Mathematics } \\
\text { Making It In Engineering }\end{array}$ \\
\hline & & $12: 15-12: 40$ & $\begin{array}{l}\text { Planning to Graduate } \\
\text { Mastering Mathematics } \\
\text { Making It In Engineering }\end{array}$ \\
\hline & & $12: 45-1: 00$ & $\begin{array}{ll}\text { Closing Session } \\
\text { Schaefer Lecture Hall } \\
\circ \quad \text { Guest Speaker(s) } \\
\circ & \text { Wrap-Up/Evaluation }\end{array}$ \\
\hline
\end{tabular}

Proceedings of the 2002 American Society for Engineering Education Annual Conference \& Exposition Copyright $@$ 2002, American Society for Engineering Education” 
TABLE 2

Workshop Content

\begin{tabular}{|c|c|c|}
\hline $\begin{array}{l}\text { Mastering Mathematics } \\
\text { - } \quad \text { Make mathematics a priority } \\
\text { - } \quad \text { Don't let the perception of } \\
\text { your mathematics } \\
\text { background prevent you from } \\
\text { going on the attack to } \\
\text { conquer mathematics } \\
\text { - Set a goal to do everything } \\
\text { you can to be successful in } \\
\text { mathematics } \\
\text { Take mathematics every } \\
\text { semester - Follow the correct } \\
\text { sequence } \\
\text { - } \text { Don't drop mathematics } \\
\text { Be prepared for class } \\
\text { Take notes and review them } \\
\text { - Utilize tutorial and academic } \\
\text { support services } \\
\text { Utilize instructor office hours } \\
\text { - Practice! Practice! Practice! } \\
\text { Allocate appropriate time to } \\
\text { study mathematics } \\
\text { Avoid making careless } \\
\text { mistakes } \\
\text { Organize and work in a } \\
\text { mathematics study group } \\
\text { Be cautious of the shaky "C" } \\
\text {-Master the subject! }\end{array}$ & 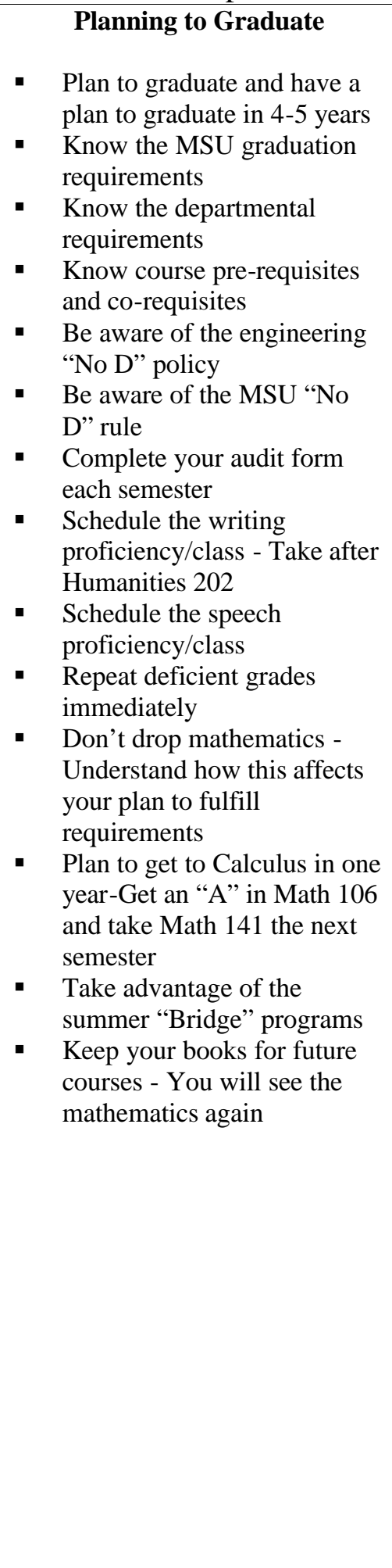 & 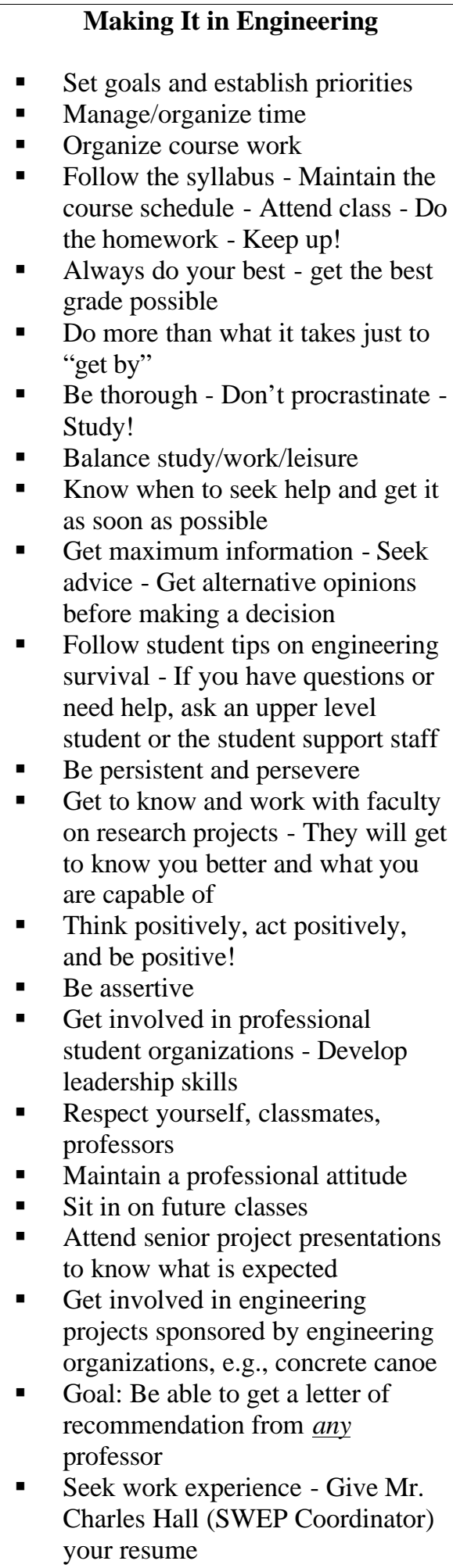 \\
\hline
\end{tabular}

Proceedings of the 2002 American Society for Engineering Education Annual Conference \& Exposition Copyright $\odot$ 2002, American Society for Engineering Education" 


\section{Program Planning and Implementation}

The Recruitment/Retention Coordinator and the Director of Freshman Programs are responsible for the Fast Track to Achievement Program. Each fall, they conduct a preliminary planning meeting with volunteer workshop facilitators where program goals, program overview, preliminary schedule, and workshop content are discussed and agreed upon. Evaluation data from the previous year is also presented. The facilitators are divided into six teams, three teams for each session. Each team conducts one workshop (Table 2). Upperclassmen initially select the workshop of their choice. However, every effort is made to balance the teams by gender and major. Each session is assigned a program manager who is responsible for moderating the general session and monitoring the activities. A team includes three facilitators and one monitor. Program managers and team members are responsible for reading the two NACME publications and the workshop notes (bullets of attention) in the program training manual. Each team member then decides which of three key points each will focus on. To standardize the workshop presentation, each of the three points must be presented consistently in each of the three workshop presentations. The workshop facilitators are required to attend a training workshop and meet at least one more time to practice and critique their presentation and to finalize the "icebreaker" they will use. To avoid confusion and save precious time, the participants remain in the same room and the facilitators rotate. The monitor is the timekeeper and is responsible for making certain the evaluation questionnaire is completed at the end of each workshop and the closing session. No staff or faculty is present at the workshop presentations. The participants receive their incentives as they leave the closing session and drop off the evaluation. A workshop session is 25 minutes and travel time for the teams is five minutes (between workshops). The workshop time is divided as follows:

- Icebreaker 5 minutes (first workshop only)

- Facilitator 13 minutes

- Facilitator 23 minutes

- Facilitator 33 minutes

- Discussion 8 minutes

- Evaluation 2 minutes

Results

In contrast to the Open Invitation Model where the level of Fast Track participation was only $50 \%$, the Integration Model increased participation to 86\% in F98, 72\% in F99, 75\% in F00, and $79 \%$ in Fall 01. In Fall 01 we examined the attendance per section, i.e., the number of students participating in Fast Track enrolled in each section of the course. Attendance for ORIE 104:001 was 91\% whereas the attendance for ORIE 104:002 was 68\%. The ORIE 104:001 students come at the regularly scheduled class period while the ORIE 104:002 students come during the "University Hour" time slot. In future programs it will be a challenge to get section two students to remember that they have a commitment during University hour, a time when there a normally no classes.

At the end of the closing session, each Fast Track to Achievement participant completes a questionnaire to evaluate each workshop and the overall program. No evaluation instrument was collected in F97, the pilot year. The results of the evaluation questionnaire administered in

Proceedings of the 2002 American Society for Engineering Education Annual Conference \& Exposition Copyright @ 2002, American Society for Engineering Education" 
F98, F99, F00, and F01 appear in Figures $1-4$ and Table 3. A positive rating selected by $80 \%$ of the participants was set as the standard for a successful program. The participants answer four questions about the program:

1. To what extent was the information presented helpful to you as an engineering student (very helpful, somewhat helpful, or not at all helpful)?

2. How much did you learn about the topics (learned a lot, learned a little, learned nothing)?

3. Did you like hearing the information from other engineering students (yes, no)?

4. Would you recommend the program for all new students in engineering (yes, no)?

Participants also rate the content (information) and delivery (way information was presented) of the workshops (Mastering Mathematics, Making It in Engineering, Planning to Graduate) as either excellent, very good, good, or fair.

The questionnaire results indicate that in F98, F99, F00, and F01, all or nearly all freshman participants liked hearing the information from other engineering students (Figure 1). In F98, F99, F00, and F01 98\%, 97\%, 99\%, and 100\% respectively of participants would recommend the program for all new students in engineering (Figure 2).
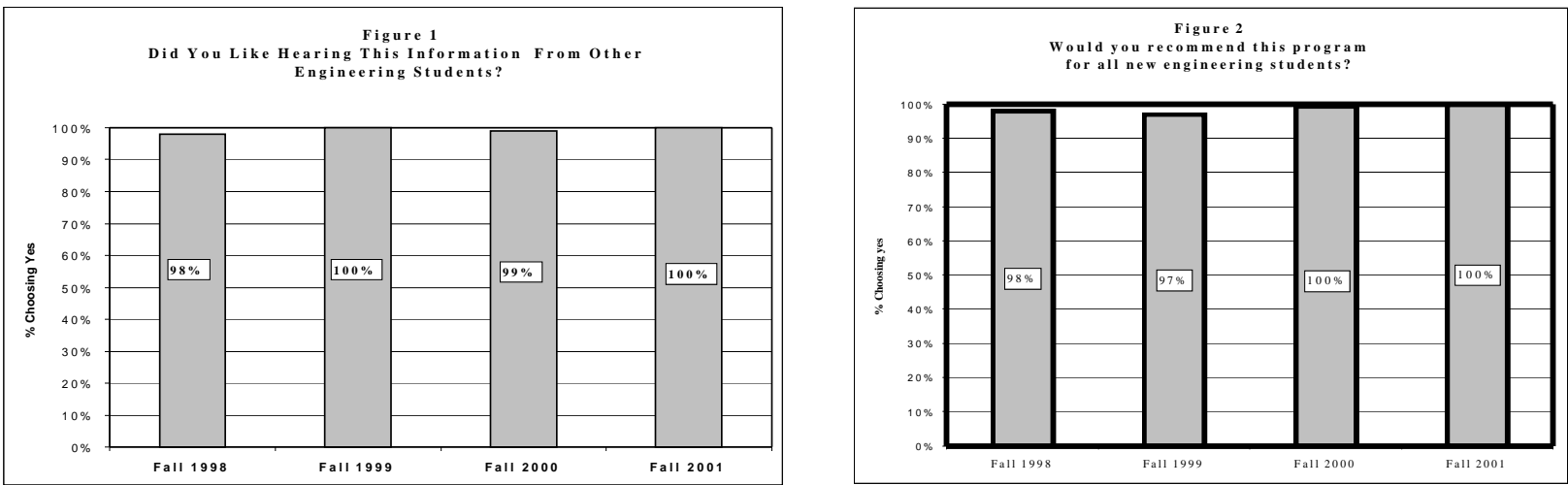

In F98, F99, and F00, 72\%-83\% of freshman participants felt they learned a lot about each topic (Figure 3). However, in F01, only 66\% felt they learned a lot. The majority of freshmen in F98, F00, and F01 felt the information presented was very helpful to them as engineering students (Figure 4). In Fall 99, however, the number of freshmen who felt that way, 76\%, also fell short of the $80 \%$ success criteria.

Table 3 compares participant ratings of the content and delivery of the workshops for the four years. In F98, F00, and F01 all three workshops exceeded the 80\% success criteria for content and delivery. The three workshops were rated positively for content by $86 \%-97 \%$ of the participants and rated positively for delivery by $81 \%$ - 97\%. In F99 only the "Making It In Engineering" workshop exceeded the $80 \%$ stand ard for content and delivery. This may have been due to the lack of experience or preparation on the part of workshop facilitators. Only two of the workshop facilitators in F99 had previous experience as Fast Track facilitators. In F00 all workshop facilitators were veterans and all three workshops exceeded the $80 \%$ success criteria for both content and delivery. 

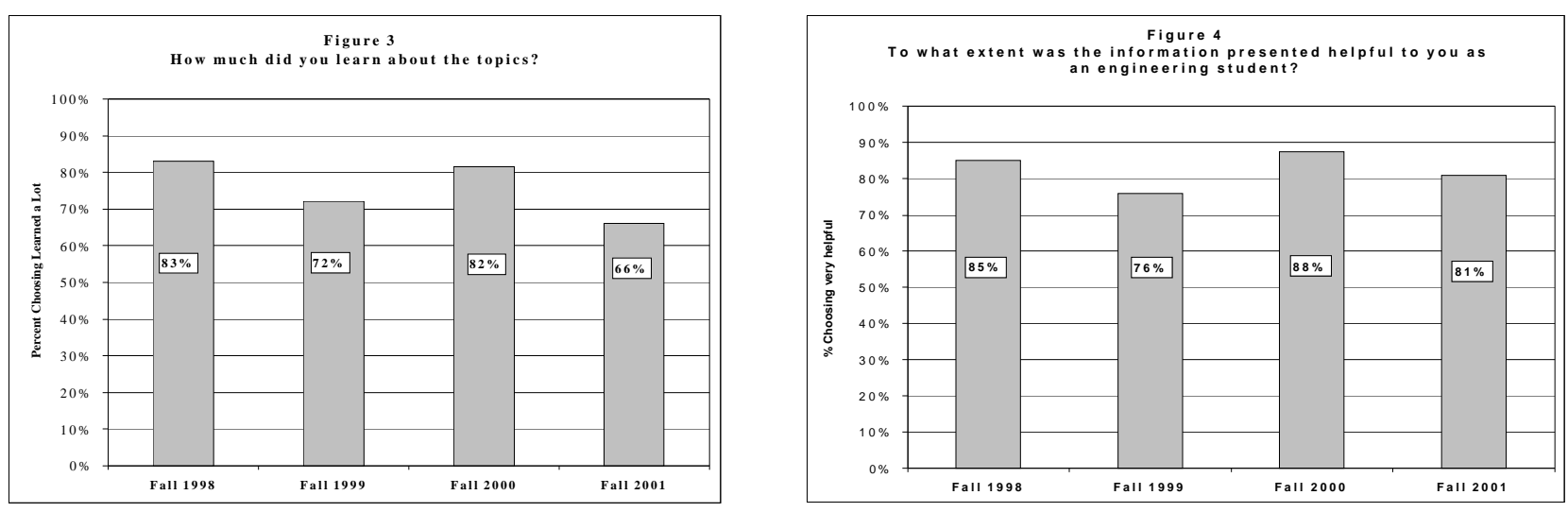

The success rate may be attributed to a more experienced group than that of the previous year, F99. A similar explanation may explain why only $66 \%$ of the F01 participants gave a "learned a lot" rating to the workshops. The class of 2001 literally wiped out the veteran Fast Track facilitators. In Fall 01, twelve of the facilitators were first-semester sophomores and only three had served as facilitators the previous year. This was a lesson learned for the administrative staff.

TABLE 3

Workshop Evaluation:

Content and Delivery Rated Very Good/Excellent

\begin{tabular}{|l|c|c|c|c|c|c|c|c|}
\hline \multirow{2}{*}{ Workshop Topic } & \multicolumn{4}{|c|}{ Content } & \multicolumn{4}{c|}{ Delivery } \\
\cline { 2 - 10 } & $\begin{array}{c}\text { Fall } \\
1998\end{array}$ & $\begin{array}{c}\text { Fall } \\
1999\end{array}$ & $\begin{array}{c}\text { Fall } \\
2000\end{array}$ & $\begin{array}{c}\text { Fall } \\
2001\end{array}$ & $\begin{array}{c}\text { Fall } \\
1998\end{array}$ & $\begin{array}{c}\text { Fall } \\
1999\end{array}$ & $\begin{array}{c}\text { Fall } \\
2000\end{array}$ & $\begin{array}{c}\text { Fall } \\
2001\end{array}$ \\
\hline Planning to Graduate & $94 \%$ & $71 \%$ & $96 \%$ & $92 \%$ & $94 \%$ & $72 \%$ & $95 \%$ & $85 \%$ \\
\hline $\begin{array}{l}\text { Mastering } \\
\text { Mathematics }\end{array}$ & $86 \%$ & $71 \%$ & $94 \%$ & $92 \%$ & $81 \%$ & $71 \%$ & $95 \%$ & $91 \%$ \\
\hline $\begin{array}{l}\text { Making It In } \\
\text { Engineering }\end{array}$ & $90 \%$ & $90 \%$ & $97 \%$ & $97 \%$ & $87 \%$ & $92 \%$ & $94 \%$ & $97 \%$ \\
\hline
\end{tabular}

Challenges During the Freshman Year and Adoption of Behaviors Recommended by Upperclassmen

As an afterthought at the end of the evaluation session in Fall 1999, the support staff asked the participants to write down (on the back of the questionnaire) the "one greatest challenge" they had faced since the beginning of the term. Although there were many answers (studying enough, staying focused, getting to early classes on time, etc.), time management was cited most often by the freshmen as the one thing that gave them the most challenge. In a follow-up to the "challenge" question, the F00 Fast Track participants responded to a prepared checklist of challenges (on the back of the evaluation questionnaire). These "challenges" were taken from the 
open-ended responses given in Fall 99. They were asked, "What have been your five greatest challenges at Morgan State University since the start of the semester?" The results (Table 4) indicated that almost half the participants cited studying enough (49\%) and time management $(48 \%)$ as one of their five greatest challenges. Staying focused was cited by $30 \%$ of participants while understanding foreign instructors $(27 \%)$, mathematics course $(26 \%)$, and finances $(25 \%)$ were cited by about one fourth of participants as challenges for the semester. This information is important because it clearly identifies areas to assist freshmen in making the transition to college during the first semester. Moreover, this checklist procedure gives students the opportunity to describe what they have experienced rather than what the support staff assumes is the most challenging, e.g., mathematics.

TABLE 4

Greatest Challenges At MSU

Since The Start of the Fall 2000 Semester

\begin{tabular}{|l|c|}
\hline \multicolumn{1}{|c|}{ Challenge Faced } & Percentage \\
\hline Studying Enough & $49 \%$ \\
\hline Time Management & $48 \%$ \\
\hline Staying Focused & $30 \%$ \\
\hline Understanding Foreign Instructors & $27 \%$ \\
\hline Math Course & $26 \%$ \\
\hline Finances & $25 \%$ \\
\hline Food/Meal & $21 \%$ \\
\hline Getting To Early Morning Classes On Time & $21 \%$ \\
\hline Science Course (Biology, Chemistry, Physics) & $20 \%$ \\
\hline Work Load & $19 \%$ \\
\hline Knowing Where To Go To Get Help/Getting Help & $19 \%$ \\
\hline Handling All My Responsibilities & $18 \%$ \\
\hline Making Friends/Meeting People & $13 \%$ \\
\hline Dealing With MSU Administration & $12 \%$ \\
\hline Instructors & $10 \%$ \\
\hline Time Constraints/Meeting Deadlines & $10 \%$ \\
\hline High School to College Transition & $10 \%$ \\
\hline English Course & $7 \%$ \\
\hline Having Self Confidence & $7 \%$ \\
\hline Adjusting to New Country Or Culture & $6 \%$ \\
\hline Distracted by Opposite Sex & $4 \%$ \\
\hline
\end{tabular}


At the end of the F00 semester, freshmen in the orientation class were again given the "challenge" checklist. This time, they were asked to name the one greatest challenge faced at Morgan State University for the entire semester. Time management (18\%), staying focused $(12 \%)$, and studying enough (12\%) were still at the top of the list (Table 5).

TABLE 5

The One Greatest Challenge

Faced at MSU During the Fall 2000 Semester

\begin{tabular}{|l|c|}
\hline \multicolumn{1}{|c|}{ Challenged Faced } & Percentage \\
\hline Time Management & $18 \%$ \\
\hline Studying Enough & $12 \%$ \\
\hline Staying Focused & $12 \%$ \\
\hline Science Course & $9 \%$ \\
\hline Math Course & $7 \%$ \\
\hline English Course & $6 \%$ \\
\hline Finances & $6 \%$ \\
\hline Getting to Early Morning Class on Time & $6 \%$ \\
\hline Handling All My Responsibilities & $5 \%$ \\
\hline Work Load & $4 \%$ \\
\hline Understanding Foreign Instructors & $3 \%$ \\
\hline High School to College Transition & $3 \%$ \\
\hline Time Constraints/Meeting Deadlines & $2 \%$ \\
\hline Distracted by Opposite Sex & $2 \%$ \\
\hline Dealing with MSU Administration & $2 \%$ \\
\hline Knowing where to go to get help/ Getting & $1 \%$ \\
\hline help & $1 \%$ \\
\hline Instructors & $0 \%$ \\
\hline Adjusting to New Country or Culture & $0 \%$ \\
\hline Having Self Confidence & \\
\hline Making Friends/ Meeting People & $1 \%$ \\
\hline Food/ Meals & $6 \%$ \\
\hline
\end{tabular}

In an effort to determine if Fast Track participants were using the information and following suggestions presented in the workshops, they were given a second checklist at the end of the semester. They were asked, "Read through the list of items below. If the statement accurately reflects your behavior during the semester, place a check in the box next to the item." The items came from the points stressed by the facilitators in the workshops (three per facilitator for each workshop). Those who did not participate in Fast Track were asked not to complete the second checklist. 
Table 6 summarizes the results of the Fast Track behavior checklist. Items are ordered by the percent of participants who checked the item as accurately reflecting their behavior. Results indicate that $50-78 \%$ of students checked ten of the recommended behaviors, $24-48 \%$ checked 13 of the recommended behaviors and $13 \%$ or less four of the behaviors.

TABLE 6

Recommended Fast Track Behavior Adopted by Fall 2000 Freshmen

\begin{tabular}{|c|c|}
\hline Behavior & Percentage \\
\hline I am planning to graduate and I have a plan to graduate in $4-5$ years & $78 \%$ \\
\hline I did not drop my mathematics course & $75 \%$ \\
\hline I know the MSU graduation requirements & $74 \%$ \\
\hline I am keeping my books for future courses & $73 \%$ \\
\hline I respected my classmates and professors & $71 \%$ \\
\hline I know my departmental graduation requirements & $70 \%$ \\
\hline I took notes in my mathematics class and reviewed them & $60 \%$ \\
\hline $\begin{array}{l}\text { I plan to take advantage of the SEM summer programs - Catch - Up, } \\
\text { Summer Research, etc. }\end{array}$ & $52 \%$ \\
\hline I made mathematics a priority & $51 \%$ \\
\hline I always thought positively, acted positively & $50 \%$ \\
\hline I asked an upper level student or the student support staff for help/advice & $48 \%$ \\
\hline I set goals and established priorities; I organized my time & $44 \%$ \\
\hline I always did my best to get the best grade possible & $43 \%$ \\
\hline I did everything possible to be successful in mathematics & $42 \%$ \\
\hline I followed the syllabus in my classes -maintained the course schedule & $39 \%$ \\
\hline I balanced study/work/leisure & $39 \%$ \\
\hline I saw a mathematics tutor & $39 \%$ \\
\hline I sought advice and got alternative opinions before making a decision & $35 \%$ \\
\hline I went to see my mathematics instructor during office hours & $34 \%$ \\
\hline I allocated sufficient time to study mathematics & $34 \%$ \\
\hline I knew when to seek help and got it as soon as possible & $33 \%$ \\
\hline I participated in a mathematics study group & $28 \%$ \\
\hline I always got involved in professional student organizations & $24 \%$ \\
\hline $\begin{array}{l}\text { I went to Mr. Charles Hall (Student Work Experience Program } \\
\text { Coordinator) about an internship or job }\end{array}$ & $13 \%$ \\
\hline I did not procrastinate & $9 \%$ \\
\hline I sat in on courses I would be taking in the future & $4 \%$ \\
\hline I got a letter of recommendation from one of my professors & $3 \%$ \\
\hline
\end{tabular}


In F01, the pre-post Fast Track questions on "challenges faced during the freshman year" were asked of the freshman participants. Results for this population are similar to those of the previous Fast Track participants. The "Big Three" -- studying enough, time management, and staying focused -- were again selected by nearly half the freshman class as the greatest challenges faced since the start of the semester (Table 7). By the end of the F01, a third of the freshman participants picked one of the "big three" as the greatest challenge faced during the semester (Table 8).

TABLE 7

Greatest Challenges

At MSU Since The Start Of The Fall 2001 Semester

\begin{tabular}{|l|c|}
\hline \multicolumn{1}{|c|}{ Challenge Faced } & Percentage \\
\hline Time Management & $57 \%$ \\
\hline Studying Enough & $50 \%$ \\
\hline Staying Focused & $45 \%$ \\
\hline Science Course (Biology, Chemistry, Physics) & $34 \%$ \\
\hline Getting To Early Morning Classes On Time & $26 \%$ \\
\hline Finances & $24 \%$ \\
\hline Understanding Foreign Instructors & $22 \%$ \\
\hline Food/Meals & $20 \%$ \\
\hline Math Course & $18 \%$ \\
\hline Work Load & $18 \%$ \\
\hline Dealing With MSU Administration & $17 \%$ \\
\hline Time Constraints /Meeting Deadlines & $15 \%$ \\
\hline English Course & $15 \%$ \\
\hline Handling All My Responsibilities & $13 \%$ \\
\hline Instructors & $12 \%$ \\
\hline Distracted By Opposite Sex & $11 \%$ \\
\hline Knowing Where To Go To Get Help/ Getting & $10 \%$ \\
\hline Help & $9 \%$ \\
\hline High School To College Transition & $7 \%$ \\
\hline Making Friends/ Meeting People & $5 \%$ \\
\hline Having Self Confidence & \\
\hline Adjusting To New Country Or Culture & $5 \%$ \\
\hline
\end{tabular}


TABLE 8

One Greatest Challenge at MSU During the Semester

\begin{tabular}{|c|c|}
\hline Challenge Faced & Percentage \\
\hline Studying Enough & $38 \%$ \\
\hline Time Management & $34 \%$ \\
\hline Staying Focused & $32 \%$ \\
\hline Finances & $23 \%$ \\
\hline Getting To Early Morning Classes On Time & $22 \%$ \\
\hline Science Course (Biology, Chemistry, Physics) & $19 \%$ \\
\hline Understanding Foreign Instructors & $19 \%$ \\
\hline Math Course & $18 \%$ \\
\hline Food/Meals & $17 \%$ \\
\hline Distracted By Opposite Sex & $13 \%$ \\
\hline Work Load & $13 \%$ \\
\hline Knowing Where To Go To Get Help/ Getting Help & $12 \%$ \\
\hline Dealing With MSU Administration & $12 \%$ \\
\hline Instructors & $11 \%$ \\
\hline Time Constraints /Meeting Deadlines & $11 \%$ \\
\hline Handling All My Responsibilities & $11 \%$ \\
\hline English Course & $10 \%$ \\
\hline High School To College Transition & $9 \%$ \\
\hline Making Friends/ Meeting People & $7 \%$ \\
\hline Having Self Confidence & $5 \%$ \\
\hline Adjusting To New Country Or Culture & $4 \%$ \\
\hline
\end{tabular}

In F01 Fast Track participants also were given a second checklist to determine if they had used any of the behaviors recommended by the Fast Track facilitators. The items came from the points stressed by the facilitators in the workshops (three per facilitator for each workshop). Those who did not participate in Fast Track were asked not to complete the second checklist. Table 9 summarizes the results of the Fast Track behavior checklist. Items are ordered by the percent of participants who checked the item as accurately reflecting their behavior. Results indicate that $52-87 \%$ of freshmen checked ten of the recommended behaviors, $24-49 \%$ checked 12 of the recommended behaviors and $17 \%$ or less six of the behaviors. 
TABLE 9

Recommended Fast Track Behavior Adopted By Fall 2001 Freshman

\begin{tabular}{|c|c|}
\hline Behavior & Percentage \\
\hline I am Planning to Graduate and I have a Plan to Graduate in Four Years & $87 \%$ \\
\hline I Respected My Classmates and My Professors & $82 \%$ \\
\hline I Know the MSU Graduation Requirements & $72 \%$ \\
\hline I Did Not Drop My Math Class & $71 \%$ \\
\hline I Know My Departmental Requirements & $67 \%$ \\
\hline I Am Keeping My Books for Future Courses & $62 \%$ \\
\hline I Took Notes in My Mathematics Class and Reviewed Them & $61 \%$ \\
\hline I Made Mathematics Priority & $57 \%$ \\
\hline I Asked an Upper-level Student or the Student Support Staff for Advice & $52 \%$ \\
\hline I Always Thought Positively, Acted Positively & $52 \%$ \\
\hline I Sought Advice - Got Alternative Opinions before Making a Decision & $49 \%$ \\
\hline $\begin{array}{l}\text { I Followed the Syllabus in My Classes; Maintained the Course Schedule - } \\
\text { Attended Classes - Kept Up! }\end{array}$ & $48 \%$ \\
\hline I Always Did my Best to Get the Best Possible Grades & $46 \%$ \\
\hline I Set Goals and Priorities - I Organized My Time & $45 \%$ \\
\hline I Did Everything Possible to be Successful in Mathematics & $45 \%$ \\
\hline $\begin{array}{l}\text { I Plan to Take Advantage of the SEM Summer Programs - Catch-Up, } \\
\text { Research }\end{array}$ & $45 \%$ \\
\hline I Balanced Study/Work/ Leisure & $40 \%$ \\
\hline I Allocated Sufficient Time to Study Mathematics & $33 \%$ \\
\hline I Knew When to Seek Help and Got It as Soon as Possible & $33 \%$ \\
\hline I Went to See My Mathematics Instructor During Office Hours & $29 \%$ \\
\hline I Saw A Mathematics Tutor & $24 \%$ \\
\hline I Participated in A Mathematics Study Group & $17 \%$ \\
\hline I Got Involved in Professional Student Organizations & $15 \%$ \\
\hline I Went to See Mr. Charles Hall (SWEP) about an Internship or Job & $13 \%$ \\
\hline I Did not Procrastinate & $11 \%$ \\
\hline I Sat in on Courses I Would be Taking in the Future & $3 \%$ \\
\hline I Got Letter of Recommendation from one of My Professors & $2 \%$ \\
\hline
\end{tabular}




\section{Academic Performance and Persistence}

The primary Fast Track strategy is to focus freshman on behaviors that promote success and achievement in engineering by introducing them to role models that can make a personal statement that engineering is both achievable and attainable. What do we know about the impact of the Fast Track to Achievement program on the academic performance and persistence of participants? This past year we examined the academic performance and retention of Fast Track participants versus non-participants for the F98, F99, and F00 cohorts. Preliminary data indicate that, in general, participation in Fast Track is associated with greater retention (Figures 5-7) and higher academic performance (Figures 8-10)
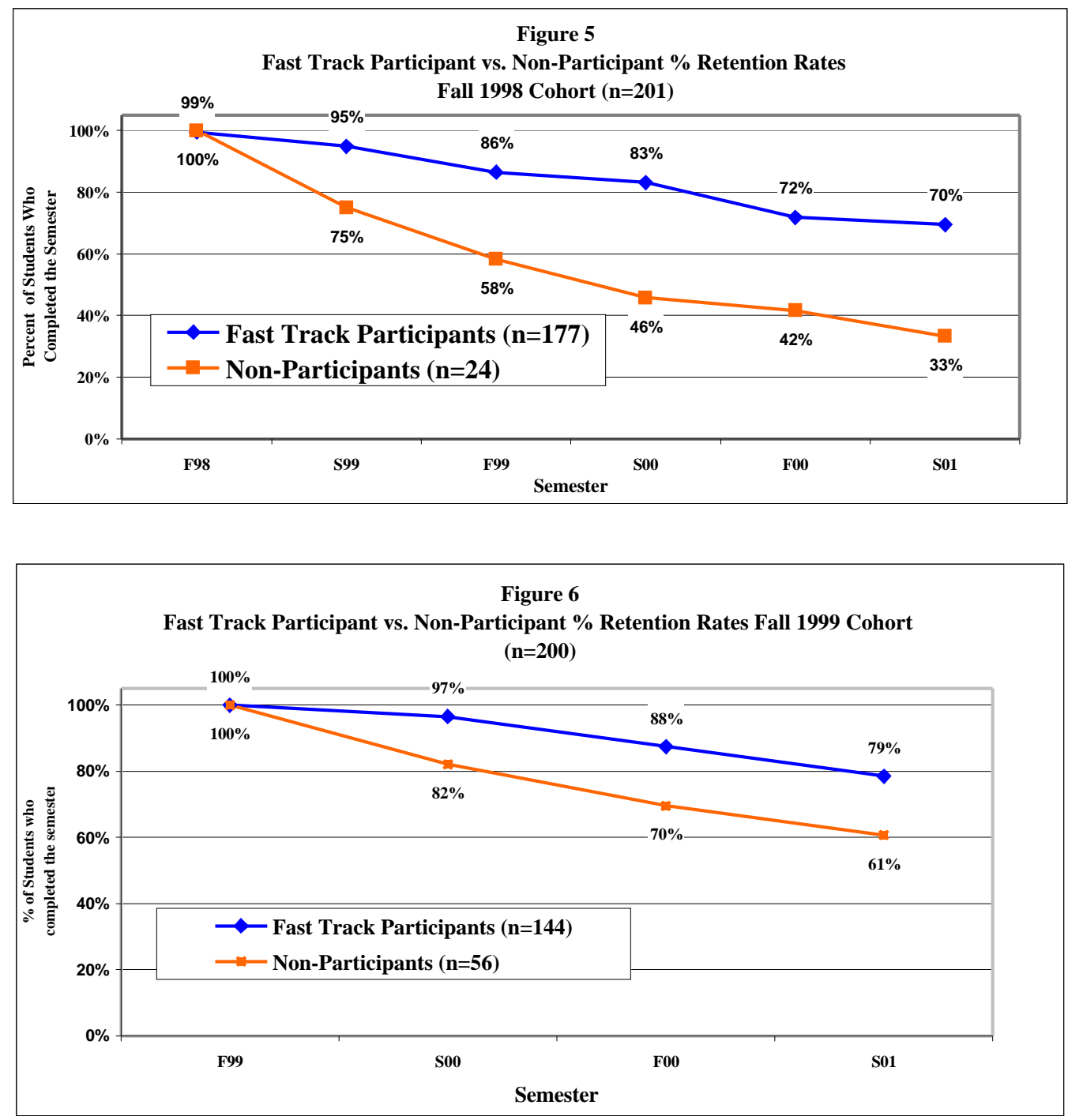

Proceedings of the 2002 American Society for Engineering Education Annual Conference \& Exposition Copyright (C) 2002, American Society for Engineering Education” 


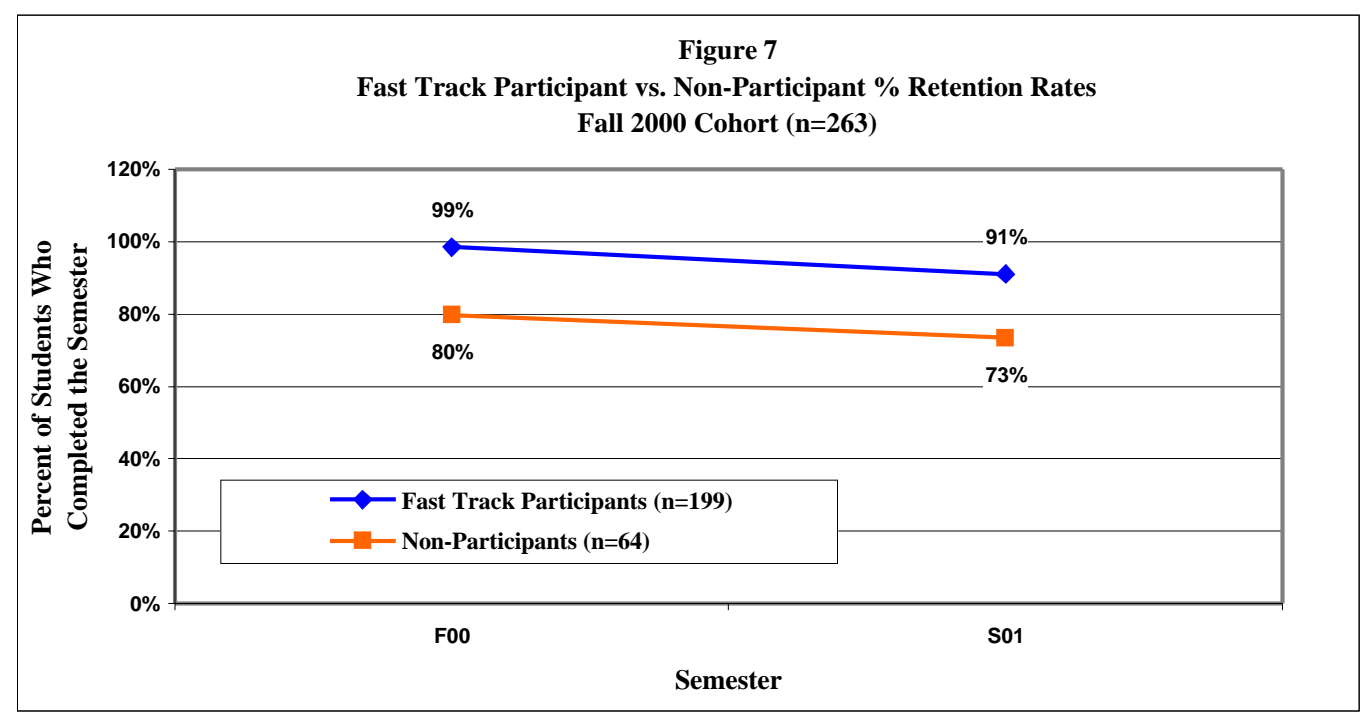

For the Fall 98 Fast Track cohort, $86 \%$ of participants returned for the sophomore year versus $58 \%$ of non-participants and $72 \%$ of participants returned for a third year versus $42 \%$ of firsttime freshmen not participating in Fast Track. For the F99 cohort, 88\% of participants returned for the sophomore year versus $70 \%$ of non-participants and for the F00 cohort $91 \%$ of them completed the freshman year versus $73 \%$ of non-participants. The average first to second year retention rate for Fast Track participants (86\% for F98 cohort and 88\% for the F99 cohort) is more than $10 \%$ above the university sophomore return rate of $74 \%$ and above the statewide retention rate which is about $80 \%$.

Figures 8-10 track the semester by semester mean cumulative grade point average (CUM GPA) for the F98, F99, and F00 cohorts. Preliminary results indicate that participation in Fast Track is associated with higher academic performance. Cumulative GPAs at the end of the freshman year for Fast Track participants were 0.5 to 0.7 of a grade point higher than those for non-participants. Cumulative GPAs at the end of the sophomore year were, on the average, 0.5 of a grade point higher than those of non-participants.

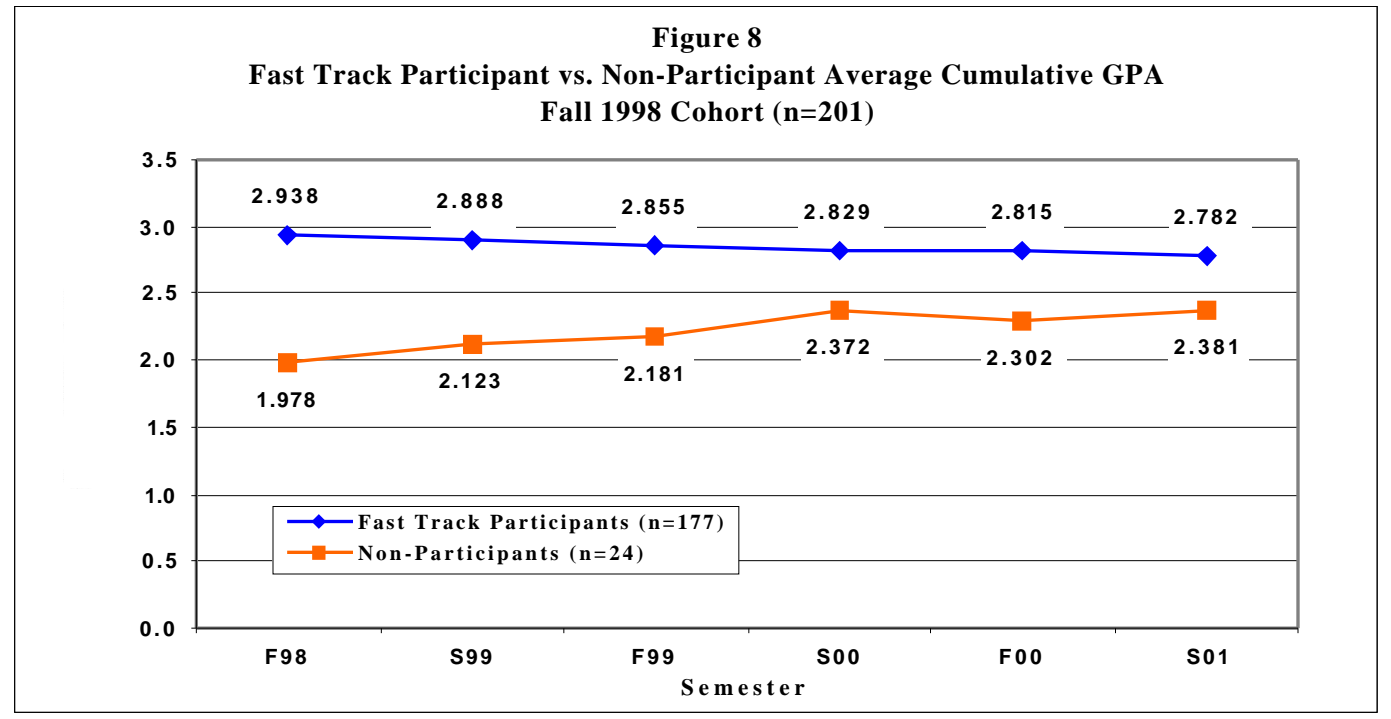

Proceedings of the 2002 American Society for Engineering Education Annual Conference \& Exposition Copyright $\odot$ 2002, American Society for Engineering Education" 


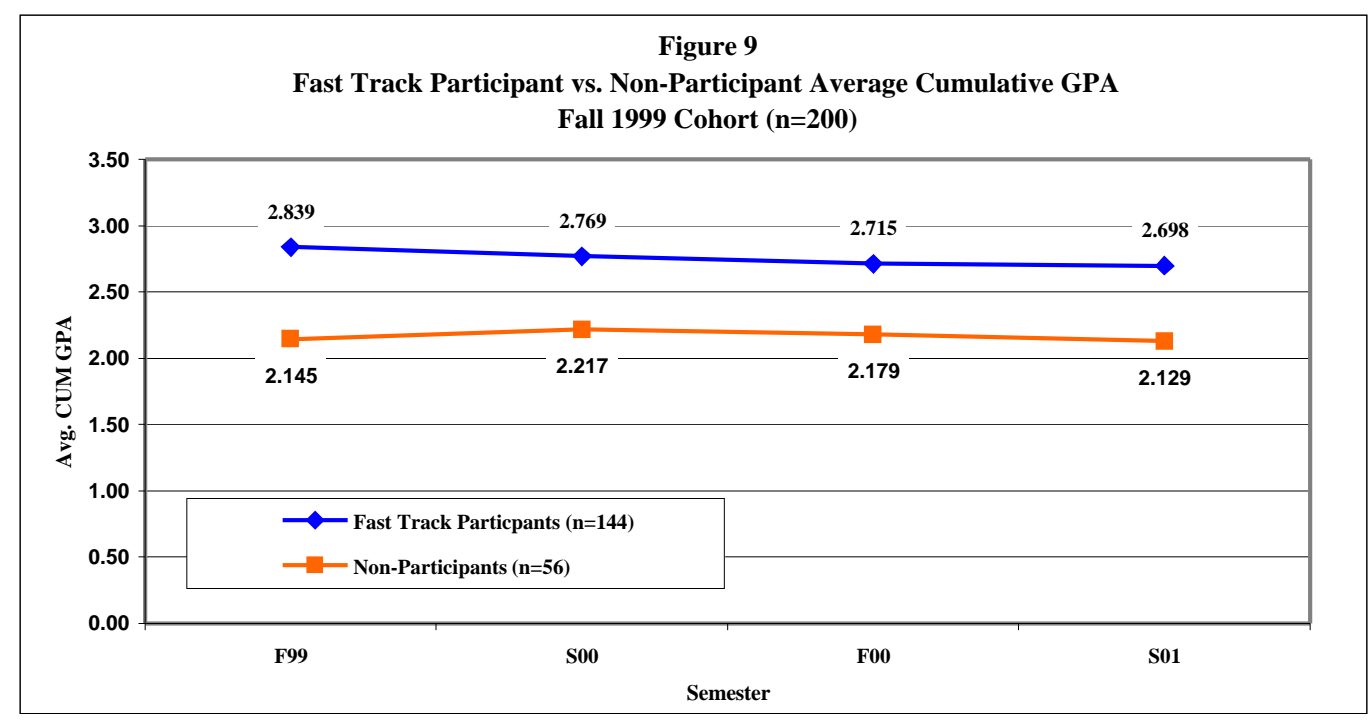

Figure 10 shows that for the F00 cohort, the end of the first year difference in mean CUM GPA between Fast Track participants and non-participants is consistent with the difference in mean CUM GPA for the F98 and F99 cohorts.

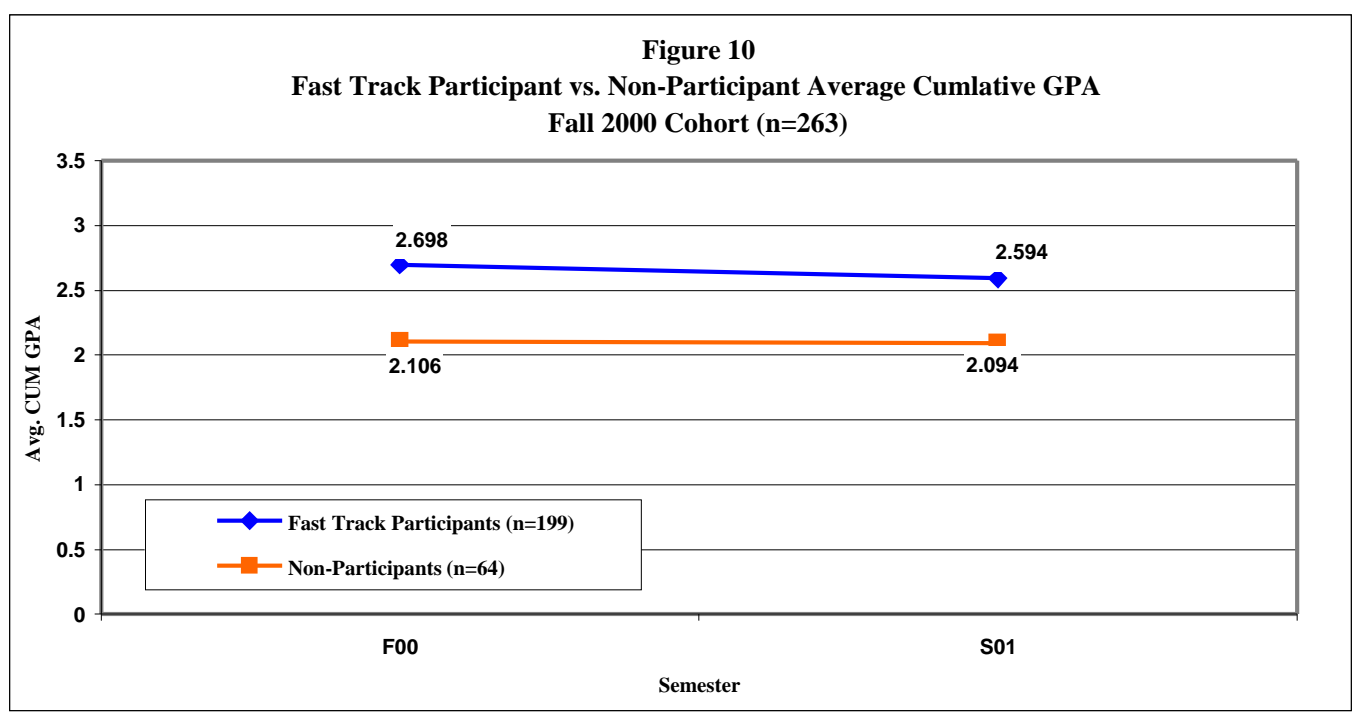

Overall, this evolving social integration program shows some promise in reaching freshmen early about the expectations for engineering students and the behaviors and attitudes necessary to be successful in engineering. Freshmen are adopting a number of behaviors recommended by upperclassmen and the program appears to be associated with higher freshman to sophomore retention rates and higher academic performance for participants. A goal of the program is to make the freshman year a year to build a foundation in engineering and the program seems to be accomplishing that goal. 


\section{Usefulness In Engineering Education}

The Fast Track to Achievement program is easily replicated, relatively inexpensive, and can be integrated into the retention effort or support services of any engineering school. It provides an opportunity for modeling successful behaviors and attitudes by the most credible source, engineering students. The program easily can evolve into a peer-mentoring program by assigning the upper classmen 2-3 freshmen to mentor and assist through the first year. This approach would be similar to the engineering undergraduate leadership and mentoring program at Oregon State University where sophomores, juniors, and seniors take a one-credit leadership course and then serve as "big brothers/sisters" to get freshmen involved early in the department through peer-group interaction ${ }^{6}$. The Freshman Interest Group Program at the University of Washington provides each student with a small community of peers who help each other negotiate the transition to college 9 . This peer interaction provides a necessary link to the engineering community and could increase the retention in engineering from freshman to sophomore year, a critical time in engineering retention, particularly for minority freshmen. According to NACME, minority freshmen that make it to the sophomore year increase their chance to graduate with a degree in engineering by about $20 \%{ }^{1}$

\section{Summary and Conclusions}

Fast Track to Achievement is a freshman retention program developed at the School of Engineering at Morgan State University. The Recruitment and Retention Coordinator, the Director of Freshman Programs, and 25-30 upperclassmen implement the program. The pilot program initiated in Fall 1997 used an Open Invitation Model to attract freshman participants. Four subsequent programs in Fall 1998, Fall 1999, Fall 2000, and Fall 2001 used an Integration Model to increase freshman participation by integrating the program into the Introduction to Engineering orientation course. Volunteer upper classmen (balanced by gender, major) in teams of 3-4 dialogue with groups of 20-30 freshmen in three workshops - Making it in Engineering, Mastering Mathematics, and Planning to Graduate. The workshops are followed by a closing session with a motivational speaker. Participants evaluate each workshop and the overall program.

Results of evaluation questionnaires collected in Fall 1998, Fall 1999, Fall 2000, and Fall 2001 indicate that 1) freshman like hearing the information from other engineering students, 2) recommend the program for all new students in engineering, and 3) feel the information is helpful to them as engineering students. A follow-up checklist administered at the end of the Fall 2000 and Fall 2001 semester, provides some evidence that participants are adopting the recommended behaviors. Moreover, participation in Fast Track appears to be associated with higher freshman to sophomore retention rates and academic performance. The Fast Track to Achievement program is a viable, relatively inexpensive retention effort. It is easy to organize and easy to replicate. It provides freshmen with a quality, first-time peer group experience as a means of encouraging them to stay linked to the engineering community, motivating them to earn the best grades, and providing resources to assist them in making the freshman year a foundation for achievement in engineering. 


\section{References}

[1] Campbell, G., Denes, R., Friedman, D., and Miyazaki, L., Minority Graduation Rates: Comparative Performance of American Engineering Schools, NACME Research Letter, 2, No. 2, 1991.

[2] Crockett, L., "Starting Off Right: Career Planning and Academic Advising in an Introductory Engineering Course" Proceedings, 1999 ASEE Annual Conference.

[3] Pascarella, E. and Chapman, D., "Predictors of Academic and Social Integration of College Students" Res. In Higher Education, 19, No. 3, 1983, 295-322.

[4] Pascarella, E. and Terenzini, P., "Predicting Voluntary Freshman Year Persistence/Withdrawal Behavior in a Residential University: A Path Analytic Validation of Tinto's Model” J. of Ed. Psychology, 75, No. 2, 1983, 215-226.

[5] Pascarella, E. and Terenzini, P., "Predicting Freshman Persistence and Voluntary Dropout Decisions from a Theoretical Model" J. of Higher Education, 51, No. 1, 1980, 60-75.

[6] Rochefort, W., "Leadership and Mentoring in Undergraduate Engineering Programs" Proceedings, 1999 ASEE Annual Conference.

[7] Terenzini, P. and Pascarella E., "Voluntary Freshman Attrition and Patterns of Social and Academic Integration in a University: a Test of a Conceptual Model" Res. in Higher Education, 6, 1977, 25-43.

[8] Tinto, V., "Dropout from Higher Education: A Theoretical Analysis of Recent Research" Rev. Ed. Research, 45, No. 1, 1975, 89-125.

[9] Tinto, V., Goodsell-Love, A. and Russo, P., "Building Community" Liberal Education, Fall 1983, $18-21$.

\section{GRACE E. MACK}

Grace E. Mack is currently Recruitment/Retention Coordinator in the Clarence M. Mitchell Jr. School of Engineering at Morgan State University. She received her BS in Psychology from Morgan State University in Baltimore, MD and a MS in Psychology from Howard University in Washington, D.C. Before coming to Morgan, she spent 15 years designing and implementing pre-college and college support programs at the University of the District of Columbia, Howard University, and the University of Michigan, Ann Arbor.

\section{JOHN A. WHEATLAND}

John A. Wheatland is currently the Director of Freshman Programs in the Clarence M. Mitchell, Jr. School of Engineering at Morgan State University. He received his BEE from the City College of New York in 1972 and his MSEE. from the University of Bridgeport in 1974. In May 2000 he received his Doctor of Education, Urban Education Leadership, from Morgan State University. Before he joined MSU in 1993, John had an eighteen-year career with IBM. He teaches the engineering orientation course, Introduction to Engineering I.

\section{KISHA L. JOHNSON}

Kisha L. Johnson is currently a Doctoral Candidate at the Clarence M. Mitchell, Jr. School of Engineering at Morgan State University. As a student at Morgan State since 1994, she received her BS in Electrical Engineering in 1999 and her MS in Electrical Engineering in 2001. She is a charter facilitator for the Fast Track to Achievement Program (1997-2001) and is currently the mentor coordinator for School of Engineering's Project SEEM (Striving for Engineering Excellence through Mentoring), an outgrowth of the Fast Track program. 